\title{
一軸および二軸伸長時の平編物の光透過性
}

\author{
信州大学繊維学部 矢崎美彦・高寺政行・清水義雄
}

\section{Light Transmission Properties of Plain Knitted Fabrics in Uniaxial and Biaxial Extension}

\author{
Yoshihiko Yazaki, Masayuki Takatera, and Yoshio Shimizu
}

Faculty of Textile Science and Technology, Shinshu University, 3-15-1, Tokida, Ueda-shi, Nagano 386-8567, Japan

\begin{abstract}
Knitted fabrics have superior expansion and contraction properties because of their loop structure. Light transmission factor is changed by extension. Light transmission properties of plain knitted fabrics stretched by uniaxial load and by biaxial load were measured, and relationship between stretch and anisotropic light transmission properties was studied. In uniaxial load, when the samples were stretched at the same extension rate along the wale direction and the course direction, they showed different light transmission factors because the stitch densities of wale and course changed with Poisson's ratio. Light transmission factor at front of a fabric was estimated from stitch densities of wale and course, Poisson's ratio of knitted fabric and diameter of yarn in stretch. In biaxial load, when the samples were extended in the same area, they showed same light transmission factors. Light transmission factor at front of a fabric was estimated from stitch densities of wale and course and diameter of yarn in stretch. It was confirmed that anisotropic light transmission properties were different by tensile conditions.
\end{abstract}

(Received 5 December, 2004; Accepted 8 February, 2005)

\section{1. 緒 言}

編物はループ構造のため, 織物に比べて伸縮性に優れて おり多孔である. そのため伸長させることにより糸間の隙 間が大きく変形し, 光透過率も変化する. 人体や体の動き にフィットすることが求められる編物製品には, ストッキ ングのように透明感が重要視されるものもあれば, 水着の ように透けにくいほうが良いものもある. このように, フ アッション性からも, 機能性からも光透過性は重要な因子 である.

布の透明感や透け具合に関しては, 編織布の透明感と光 学的パラメータとの関係について菅野ら[1]の, 衣服内に ある膚と下着の色や境目の透け具合と, 空間や脚の内腿に 囲まれた部分の透け具合に関する研究について吉野ら [2] の報告がある. また, 原糸の光透過性に注目したパンティ ストッキングの視感と色彩, 光透過, 階調輝度分布といっ た光学特性との関係について松本ら[3], 諸岡ら[4,5]の報告 がある.なお, 織物の伸長にともなう反射特性の変化につ いては成瀬ら[6], 日下部ら[7]の報告がある. 我々は, 平 織物の光透過異方性の測定を行ない構造からの予測を検 討した[8]. 比較的粗く製織された平織物であれば上下, 左右対称な構造であり, 織物の幾何学的構造と織物の正面 から光を照射したときの光透過率から光透過異方性を予
測することができた.

編物は立体構造であり, 伸長により構造が大きく変化す る. よって, 伸長率や光の当たり方により光透過性にも変 化があると考えられる. しかし, これまでの研究は編物の 反射特性や視覚的評価であり, 伸長率に伴う編構造の変形 や異方性を考慮した光透過性の評価はされていない. 編物 は編み方により様々な立体構造を形成することができる. 特に緯編物は伸縮性がよく,なかでも平編は構造が単純で 薄手であり光透過性が良い. 本研究では緯編物の伸長に伴 う構造の変化, すなわち空隙の変化と光透過性との関係を 明らかにするため, 一軸扔よび二軸伸長時における平編物 の光透過性の異方性測定を行ない, それぞれ編構造から伸 長時の光透過率を予測することを目的とし,さらに伸長条 件と光透過異方性との関係を検討した.

\section{2. 理 論}

\section{1 光透過異方性}

入射光の照度を $I_{i}\left(\mathrm{~lm} \cdot \mathrm{m}^{-2}\right)$, 透過光の照度を $I_{t}\left(\mathrm{~lm} \cdot \mathrm{m}^{-2}\right)$ と すると, 光透過率 $T(\%)$ は式 1 のようになる.

$T=\frac{I_{t}}{I_{i}} \times 100$

編物に光が当った場合, その入射光は主に空隙 (糸間の 
隙間）を透過する光, 糸の内部を透過する光, 糸の表面で 反射, 拡散する光, 糸の内部に吸収される光の 4 つに分け られる.この内, 空隙を透過する光と, 系の内部を透過す る光を合わせたものが編物の透過光である. また, 光透過 異方性とは光の入射方向の違いにより光透過率が異なる ことである. 図 1 に示すように編物平面を X-Y 平面とす ると, 試料に対する光の入射方向は, 方位角 $(\beta)$ 方向と仰 角 $(\alpha)$ 方向の 2 つの角度により決まる.

この 2 つの角度の変化に伴い, 異方性が現れる. 糸の光 透過率が 0 であれば, 編物の光透過率は空隙を透過する光 のみを考慮すればよい. 平編物の場合は構造が上下, 左右 対称と仮定すると, 異方性にも対称性があることが考えら れる.

\section{2 伸長による平編物の変形と光透過率の変化}

\section{2.1 一軸伸長による変形}

図 2 のように, 編物を一軸伸長すればポアソン効果によ り伸長方向に垂直な方向には縮む. よって, ウェール密度 およびコース密度は伸長方向には減少し, 伸長方向に垂直 な方向には増加する. $W$ を伸長前のウェール密度, $C$ を伸 長前のコース密度とすると, 縦ひずみ $\varepsilon$, 横ひずみ $\varepsilon$ 'と ポアソン比 $v$ の関係

$v=\frac{\varepsilon^{\prime}}{\varepsilon}, \quad \varepsilon^{\prime}=\varepsilon v$

から, 一軸伸長時のウェール密度 $W^{\prime}$, コース密度 $C^{\prime}$ は次 のようになる.

ウェール方向に伸長したとき

$W^{\prime}=\frac{W}{1-\varepsilon^{\prime}}=\frac{W}{1-\varepsilon v_{W}} \quad, \quad C^{\prime}=\frac{C}{\varepsilon+1}$

コース方向に伸長したとき

$W^{\prime}=\frac{W}{\varepsilon+1} \quad, \quad C^{\prime}=\frac{C}{1-\varepsilon^{\prime}}=\frac{C}{1-\varepsilon v_{C}}$

ここで,

$v_{W}:$ ウェール方向に伸長した時のポアソン比

$v_{C}:$ コース方向に伸長した時のポアソン比

編物の対称性を考え, 編目の単位領域を長方形とすると, その横の長さ $w$ はウェール間隔の半分に, 縦の長さ $c$ は コース間隔と同等であり, 次のようになる.

$w=\frac{1}{2 W^{\prime}} \quad c=\frac{1}{C^{\prime}}$

また, 毛糸のようなかさ高い糸では伸長に伴い糸の直径も 減少することが考えられる. そこで, 伸長時の糸の直径を d'とすると空隙部の割合, すなわち透過率 $T$ は次のように なる.

$T=\frac{\left(w-d^{\prime}\right)\left(c-d^{\prime}\right)}{w c} \times 100 \quad[\%]$

よって, 式 6 が成立するとき $W, C, v_{W}, v_{C}, d$ が分か れば, 一軸伸長時における試料正面から光を照射したと きの透過率を予測できる.

\section{2.2 二軸伸長による変形}

ストッキングやタイツなどの着装状態を考えると, 編地 はウェール, コース両方向へ伸長している.
図3 のように, 一軸を拘束して伸長した場合, ウェール 密度およびコース密度は, 拘束側は変化せず伸長側は伸長 率に反比例して減少すると考えられる.よって, 二軸伸長 時のウェール密度 $W$, コース密度 $C$ 'は次のようになる。 $W^{\prime}=\frac{W}{\varepsilon_{C}+1} \quad C^{\prime}=\frac{C}{\varepsilon_{W}+1}$ ここで,

$\varepsilon_{W}:$ ウェール方向のひずみ, $\varepsilon_{C}:$ コース方向へのひずみ よって, 伸長方向に関わらず同面積に伸長させた場合, 単 位面積あたりの編目数である $W^{\prime} \times C^{\prime}$ は同じ値となる.

一軸伸長時と同様に編目の単位領域を長方形とすると, $W, C, d^{\prime}$ が分かれば,式 7，5，6 より二軸伸長時における 試料正面から光を照射したときの透過率を予測できる.

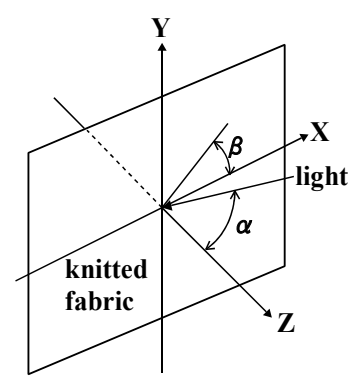

Fig. 1 Courses of light.

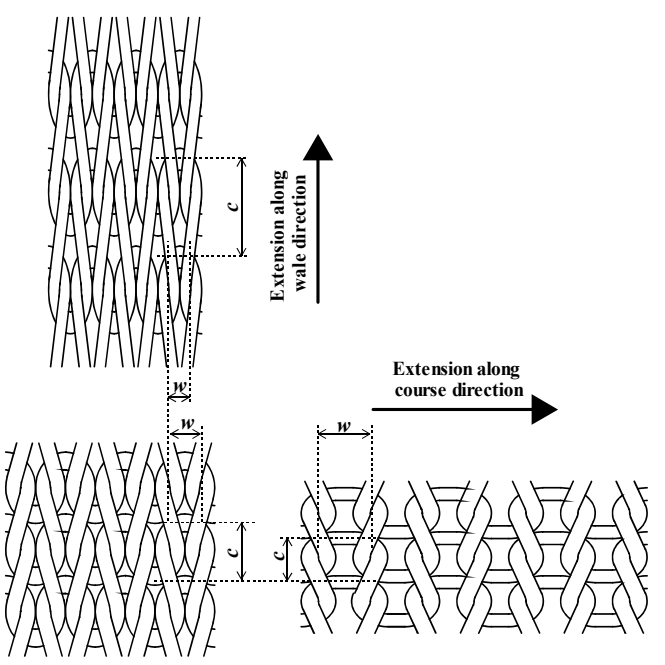

Fig. 2 Uniaxial exension model.

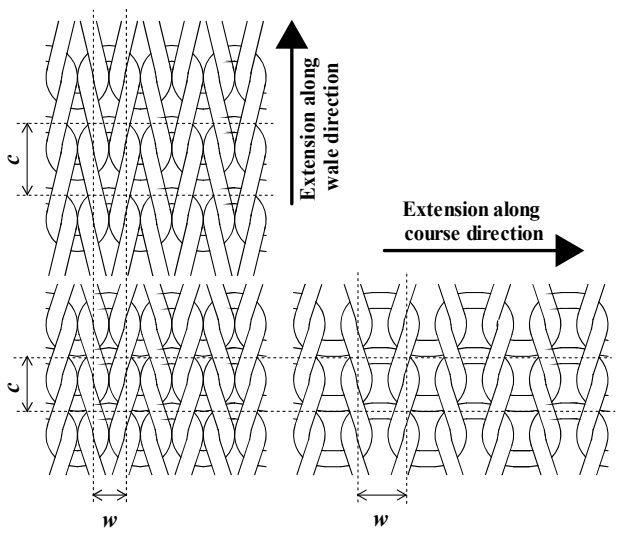

Fig. 3 Biaxial extension model. 


\section{3. 実 験}

\section{1 光透過率測定装置}

光透過率の測定には, 平織物の光透過異方性の測定 [8] と同様の装置を用いた. 図 4 に装置の概略を示す. 試料に 光を当て透過した光量を照度計で測定する. 回転台 1,2 の二つの回転により角度 $\alpha, \beta$ がれぞれ変化し, 異方性 の測定が行なえる.

\section{2 試料}

無伸長状態で空隙率の異なる編地として編目密度の異 なる 2 種類の平編物を横編機（島精機 SEC-161FF）で編 成した. 原糸は紺色の毛糸を 2 本引きそろえて用いた. 原 糸の詳細を表 1 に示す. 原糸自体の光透過率を測定するた め, 複数の原糸を平行に揃え $20 \mathrm{~mm} \times 20 \mathrm{~mm}$ の大きさにし て図 4 の装置により測定を行なった. その結果, 光透過率 は $0.63 \%$ 以下と僅少であったので原糸の光透過率は無視 できるものとした.

試料は, 図 5 に示すように伸長させた状態で， $100 \mathrm{~mm}$ $\times 100 \mathrm{~mm}$ で中央に長径 $80 \mathrm{~mm}$ の穴をあけた 2 枚の板で挟 み接着し, 装置に取付けた. 伸長方法は以下の 2 通りの方 法を用いた。

(a) 一軸伸長

通常のチャックを用いる一軸引張試験では, チャック部の 拘束によりにより均一な単純引張状態にすることはでき ない，そこで, チャックの影響を低減する方法として, 図 6に示すローラクランプ[9]を作製し用いた. 試料をループ 状に縫製し, 回転自由な 2 本のローラで試料を引張る. ロ 一ラと試料との接触部分では試料がローラの表面上を自 由に移動できるため, 支持部の拘束を低減することができ, ポアソン効果を考慮した伸長が可能である. 万能引張試験 機（東洋ボールドウィン社 UTM-III-100）にローラクラン プを取付け伸長した. 試料寸法はランやカールの影響が小 さくなるように十分な幅を有しかつ, 均一な変形となるよ うな長さとして，430 mm（内縫い代 $30 \mathrm{~mm} ） \times 200 \mathrm{~mm}$ と した.これを, 綿縫糸を用いてミシンで二重縫いを扔こな いループ状とした. 表 2 に, 光透過率の測定に用いた試料 の伸長率を示す。

以下，試料名を次のように表記する。

例： $\mathrm{A}_{\mathrm{u}} \mathrm{W} 50$ (試料 A, 一軸伸長, ウェール方向への伸長率 $50 \%)$

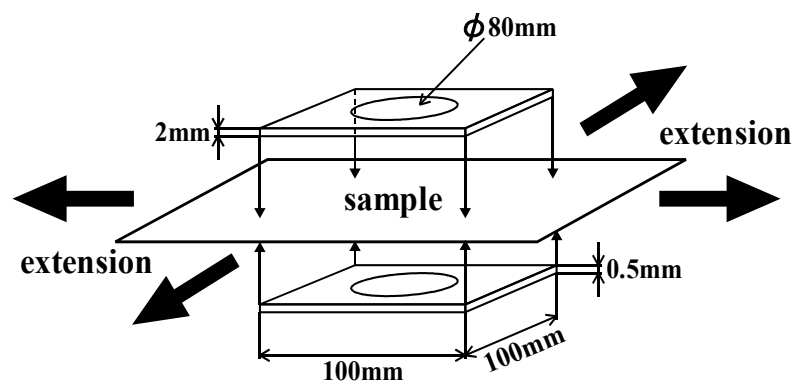

Fig. 5 Sample making method.
Table 1 Details of yarn.

\begin{tabular}{|c|c|c|c|c|c|}
\hline \multirow{2}{*}{$\begin{array}{c}\text { sample } \\
\text { name }\end{array}$} & \multirow{2}{*}{ fiber } & \multirow{2}{*}{$\begin{array}{c}\text { yarn } \\
\text { fineness } \\
\text { (tex) }\end{array}$} & \multicolumn{2}{|c|}{ stitch density } & \multirow{2}{*}{$\begin{array}{l}\text { loop } \\
\text { length } \\
(\mathrm{cm})\end{array}$} \\
\hline & & & $\begin{array}{c}\begin{array}{c}\text { wales } \\
\mathrm{cm}^{-1}\end{array} \\
\end{array}$ & $\begin{array}{c}\text { courses } \\
\mathrm{cm}^{-1}\end{array}$ & \\
\hline A & $\begin{array}{l}\text { wool } \\
60 \%\end{array}$ & & 2.9 & 4.4 & 1.26 \\
\hline B & $\begin{array}{c}\text { acrylic } \\
40 \%\end{array}$ & $33 / 2$ & 2.4 & 3.4 & 1.49 \\
\hline
\end{tabular}

Table 2 Extension of samples (uniaxial extension).

\begin{tabular}{ccc}
\hline \multirow{2}{*}{ sample } & \multicolumn{2}{c}{ extension $(\%)$} \\
\cline { 2 - 3 } & wale direction & course direction \\
\hline A & $0,25,50$ & $0,25,50,75$ \\
\hline B & $0,25,50$ & $0,25,50,75$ \\
\hline
\end{tabular}

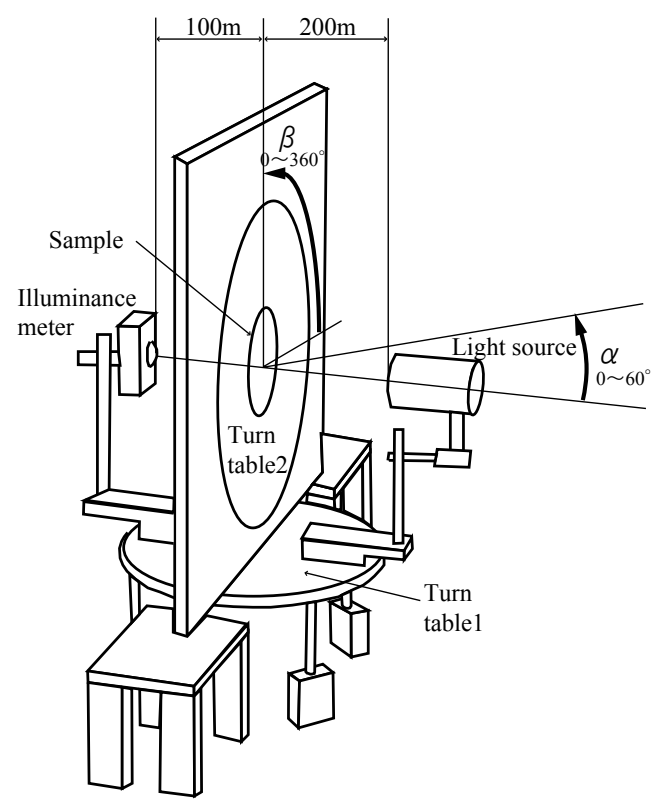

Fig. 4 Measurement device.

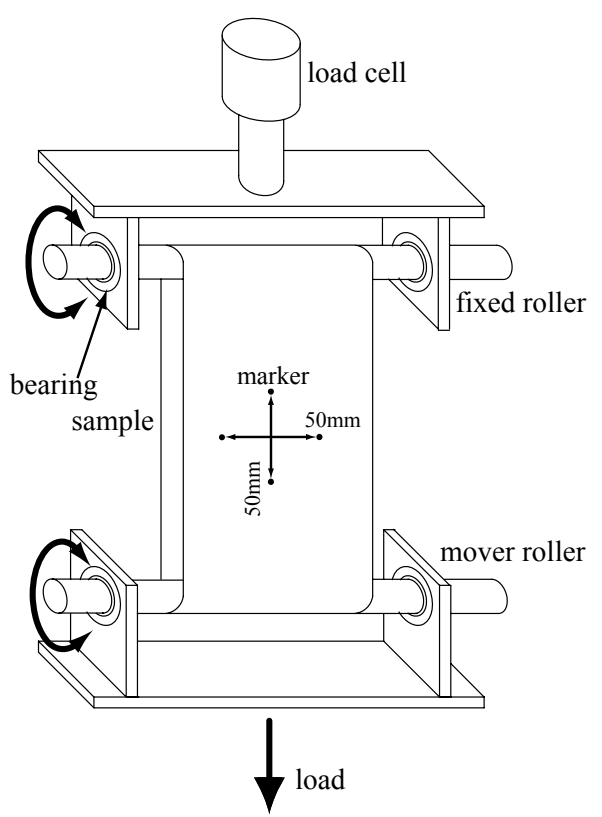

Fig. 6 Roller clamps. 
Table 3 Extension of samples (biaxial extension).

\begin{tabular}{cll}
\hline \multirow{3}{*}{ sample } & \multicolumn{2}{c}{ extension (\%) } \\
\cline { 2 - 3 } & wale direction & \multicolumn{1}{c}{ course direction } \\
\cline { 2 - 3 } & \multicolumn{1}{c}{0} & $0,10,20,30,40,50,60$ \\
\cline { 2 - 3 } A & 10 & $0,10,20,30$ \\
\cline { 2 - 3 } & 20 & $0,10,20$ \\
\cline { 2 - 3 } & 30 & 0,10 \\
\cline { 2 - 3 } & 40 & 0 \\
\hline & 50 & 0 \\
\cline { 2 - 3 } & 0 & $0,10,20,30,40,50,60,70$ \\
\hline & 10 & $0,10,20,30$ \\
\hline & 20 & $0,10,20,30$ \\
\hline & 30 & $0,10,20,30$ \\
\hline & 40 & 0 \\
\cline { 2 - 3 } & 50 & 0 \\
\cline { 2 - 3 } & 60 & 0 \\
\hline
\end{tabular}

(b) 二軸伸長

二軸引張試験機（カトーテック(株)KES-G2-SB1）によ り伸長した. 試料寸法は $140 \mathrm{~mm} \times 165 \mathrm{~mm}$ (有効寸法 $115 \mathrm{~mm}$ ×100mm）で, ランが生じないようにクランプ部より外側 の周囲を, 綿糸を用いて縫った. 表 3 に示すように, 一軸 を拘束して伸長した試料と, 二軸両方向へ伸長した試料を 作製した。

以下，試料名を次のように表記する.

例: $\mathrm{A}_{\mathrm{b}} 0-10$ (試料 $\mathrm{A}$, 二軸伸長, ウェール方向への伸長率 $0 \%$, コース方向への伸長率 $10 \%$ )

$\mathrm{A}_{\mathrm{u}} \mathrm{W} 0, \mathrm{~A}_{\mathrm{u}} \mathrm{C} 0, \mathrm{~A}_{\mathrm{b}} 0-0$ および $\mathrm{B}_{\mathrm{u}} \mathrm{W} 0, \mathrm{~B}_{\mathrm{u}} \mathrm{C} 0, \mathrm{~B}_{\mathrm{b}} 0-0$ は無伸 長であり, 同一試料である.

\section{3 測定方法}

\section{3.1 光透過異方性測定}

異方性測定における二方向の角度 $\alpha, \beta$ の内, $\beta$ の変化 に伴う異方性に重点をおいた測定方法として, 次の測定を 行なった. $\alpha$ を $0^{\circ} \sim+60^{\circ}$ まで $15^{\circ}$ おきに回転させる. それぞれの $\alpha$ において, $\beta$ を $0^{\circ} \sim+360^{\circ}$ まで自動回転さ せながら透過光の照度を約 $1^{\circ}$ 間隔で測定し, 移動平均 (5 点)によりノイズを除いた. 予備実験の結果, 試料の表目, 裏目によって測定值に異なる傾向は見られず測定值もほ ぼ同等であったので, 表目と裏目をそれぞれ測定し平均し た. 試料無装着時の照度も測定し, これを $I_{i}$ とし, 式 1 に 代入し透過率を求めた.

\section{3.2 原糸の引張試験}

試料の原糸の引張試験を行ない, 原糸の直径と荷重との 関係を求めた. 原糸 $200 \mathrm{~mm}$ を万能引張試験機（東洋ボー ルドウィン社 UTM-III-100）を用い，引張速度 $0.1 \mathrm{~mm} \cdot \mathrm{s}^{-1}$ で 0 4\%まで伸長した. 同時に, デジタルカメラ (FUJIFILM FinePix S2pro）を用い, $0.5 \mathrm{~mm}$ 間隔で原糸を撮影し（解像 度 610dpi), 画像を二值化 (判別分析法) し直径を求めた. ただし，試料は原糸を 2 本引きそろえて編んであるため, 荷重, 直径ともに測定值を 2 倍した.

\section{3. 3 編物の引張試験}

編物の引張試験を行ない, 編物の伸長時に原糸 1 本にか かる荷重を測定した.この結果と原糸の引張試験の結果と を対応させることにより, 式 6 に必要な伸長時の原糸の直 径 $d$ 'が求まる.

(a) 一軸伸長

試料作製時と同様に, 万能引張試験機にローラクランプ を取付け引張試験を行った. 試料寸法は試料作製時と同等 で, 初荷重 $3 \mathrm{gf} \cdot \mathrm{cm}^{-1}$ を負荷した. 引張速度 $0.2 \mathrm{~mm} \cdot \mathrm{s}^{-1}$ で伸 長した. ポアソン比を求めるために, 試料に図 3 のような $50 \mathrm{~mm}$ 四方のマーカーをつけ伸長過程をデジタルカメラ により $10 \mathrm{~mm}$ 間隔で撮影した.

試料はループ状なので式 8 のように荷重 $F\left(\mathrm{gf} \cdot \mathrm{cm}^{-1}\right)$ を半 分にし, さらにウェール密度またはコース密度で除し, 糸 1 本（実際は 2 本引きそろえた状態）あたりにかかる荷重 $N(\mathrm{gf})$ 算出した. ウェール方向には, 一つの編目あたり 2 本分の荷重がかかるので, ウェール密度を 2 倍にして除し た.

$N=\frac{F}{4 W}$ または, $N=\frac{F}{2 C}$

(b) 二軸伸長

二軸引張試験機を用い, 引張速度 $0.25 \mathrm{~mm} \cdot \mathrm{s}^{-1}$ で弓張試 験を行った. 試料寸法は試料作製時と同等で, 初荷重 $3 \mathrm{gf} \cdot$ $\mathrm{cm}^{-1}$ を負荷した. 式 9 のようにウェール方向, コース方向 にかかる荷重 $F_{W}, F_{C}\left(\mathrm{gf} \cdot \mathrm{cm}^{-1}\right)$ をウェール密度およびコー 又密度で除し平均して, 糸 1 本 (実際は 2 本引きそろえた 状態）あたりにかかる荷重 $N(\mathrm{gf})$ を算出した. 一軸伸長時 と同様に, ウェール方向は, ウェール密度を 2 倍にして除 した.

$N=\frac{1}{2}\left(\frac{F_{w}}{2 W}+\frac{F_{C}}{C}\right)$

\section{4. 結果および考察}

\section{1 一軸伸長時の光透過性}

\subsection{1 伸長による編目密度の変化}

図 7 に伸長に伴うウェール密度およびコース密度の変 化を示す． 2.2 .1 で述べた通り伸長方向にはウェール密度 またはコース密度は減少し, 伸長方向に垂直な方向には増 加した. 図 8 に縦ひずみと横ひずみの関係を示す.この図 から分かるように, 試料 A, B ともに縦ひずみと横ひずみ の関係が線形となっており, ほぼ均一に変形していること が分かる.よって, この図の傾きよりポアソン比を求めた. その結果, 試料 A では $v_{W}=0.83, v_{C}=0.50$, 試料 $\mathrm{B}$ では $\nu_{W}=0.76, \quad v_{C}=0.56$ となった.

\section{1.2 光透過率の測定值と理論值の比較}

図 9 に原糸の直径と荷重との関係を示す. 荷重の増加に 伴い直径は減少するが, 約 $17 \mathrm{gf}$ までの荷重が小さいとき に糸の直径は急激に減少しその後, 緩やかに減少している. よって, 伸長率が小さいときでも原糸の直径の変化は大き く, 光透過率には糸の直径を考慮しなければならない. 表 
4 に式 8 より求めた, 試料の原糸 1 本あたりに掛かる荷重 を示す.この值と図 9 の関係から伸長時の原糸の直径を求 め, 式 6 より光透過率の理論值を求めた. 図 10 に光を試 料正面から照射したときの, 光透過率の測定值と理論值 との比較を示す. ウェール方向に伸長させた場合は, 伸 長に伴い透過率は減少した. コース方向に伸長した場合は, 最初は伸長に伴い透過率が増加するがその後は減少して いった. これは, ポアソン比の違いによりウェール密度と コース密度との変化が異なるためである. 試料 AuW50 と BuW50 の測定值と理論值が大きく異なるのは, 図 2 に示 した $w$ が原糸の直径 $d^{\prime}$ よりも狭くなり, 糸が潰れたり重 なりあったりジャミングしているためである. しかし, 他 の試料については測定值と理論值はほぼ等しくなった.よ って, ジャミングが起きない範囲で伸長した場合は, 無伸 長時のウェール密度, コース密度, 伸長時の原糸の直径, ポアソン比が分かれば, 伸長状態での光を正面から照射し たときの光透過率を予測することができる.

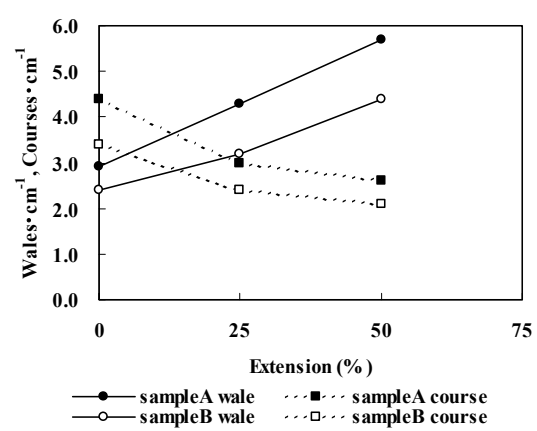

(a) Extension along wale direction.

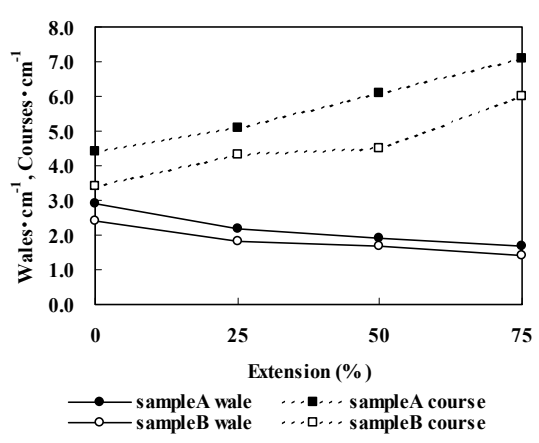

(b) Extension along course direction.

Fig. 7 Relationship between extension and stitch density of wale or course (uniaxial extension).

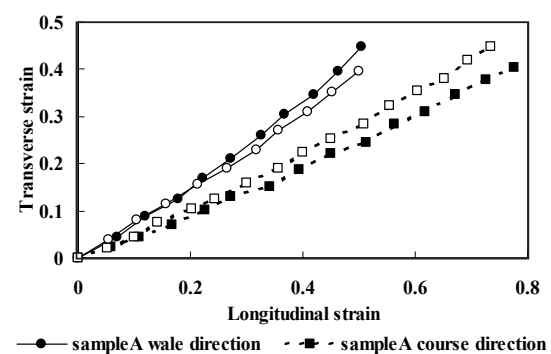

- - sampleA wale direction $\quad--$ - sampleA course direction

Fig.8 Relationship between transverse strain and longitudinal strain.

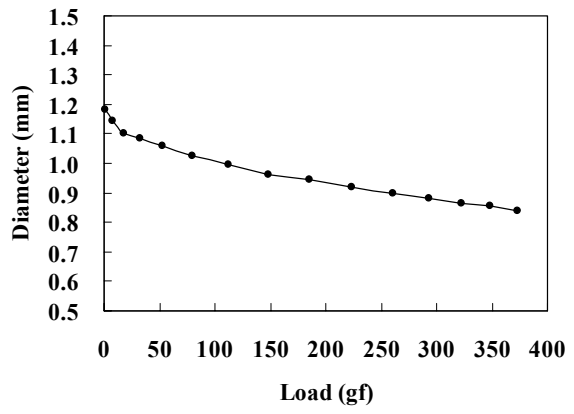

Fig. 9 Relationship between load and diameter of yarn.

Table 4 Calculated load of yarn in fabric (uniaxal extension). Sample A

\begin{tabular}{cccc}
\multicolumn{4}{c}{ Sample A } \\
\hline $\begin{array}{c}\text { sample } \\
\text { name }\end{array}$ & $\begin{array}{c}\text { load } \\
(\mathrm{gf})\end{array}$ & $\begin{array}{c}\text { sample } \\
\text { name }\end{array}$ & $\begin{array}{c}\text { load } \\
(\mathrm{gf})\end{array}$ \\
\hline $\mathrm{A}_{\mathrm{u}} \mathrm{W} 0$ & 0.00 & $\mathrm{~A}_{\mathrm{u}} \mathrm{C} 0$ & 0.00 \\
\hline $\mathrm{A}_{\mathrm{u}} \mathrm{W} 25$ & 3.16 & $\mathrm{~A}_{\mathrm{u}} \mathrm{C} 25$ & 1.66 \\
\hline $\mathrm{A}_{\mathrm{u}} \mathrm{W} 50$ & 13.36 & $\mathrm{~A}_{\mathrm{u}} \mathrm{C} 50$ & 3.03 \\
\hline- & - & $\mathrm{A}_{\mathrm{u}} \mathrm{C} 75$ & 5.35 \\
\hline \multicolumn{4}{c}{ Sample B } \\
\hline sample & load & sample & load \\
name & $(\mathrm{gf})$ & name & $(\mathrm{gf})$ \\
\hline $\mathrm{B}_{\mathrm{u}} \mathrm{W} 0$ & 0.00 & $\mathrm{~B}_{\mathrm{u}} \mathrm{C} 0$ & 0.00 \\
\hline $\mathrm{B}_{\mathrm{u}} \mathrm{W} 25$ & 1.91 & $\mathrm{~B}_{\mathrm{u}} \mathrm{C} 25$ & 1.35 \\
\hline $\mathrm{B}_{\mathrm{u}} \mathrm{W} 50$ & 5.99 & $\mathrm{~B}_{\mathrm{u}} \mathrm{C} 50$ & 2.45 \\
\hline- & - & $\mathrm{B}_{\mathrm{u}} \mathrm{C} 75$ & 4.29 \\
\hline
\end{tabular}

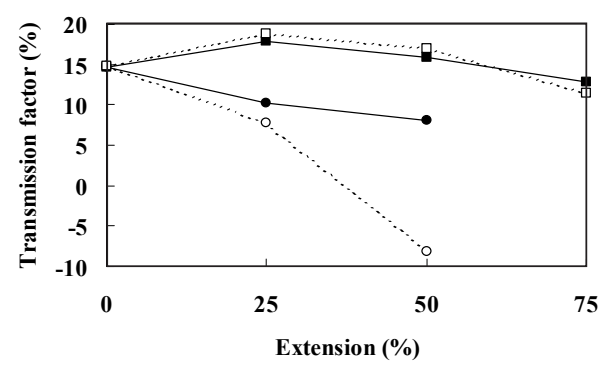

$\longrightarrow$ wale direction measured $\quad \ldots 0 \ldots$ wale direction theoretical

(a) Sample A

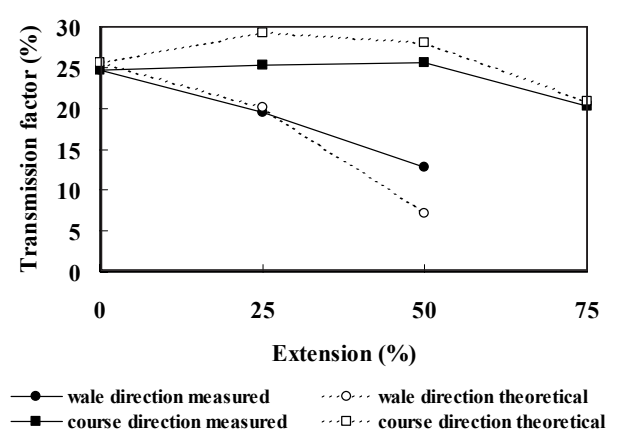

(b) Sample B

Fig. 10 Comparison between measured and theoretical values of light transmission factor (uniaxial extension). 


\section{1.3 光透過異方性}

図 11 に試料 $\mathrm{B}_{\mathrm{u}} \mathrm{C} 75$ の $\alpha$ の変化に対する光透過率を示す. $\alpha$ が大きくなるにつれ光透過率に異方性が現れた. 他の試 料についても同様であった. 図 12 に, 試料 B の $\alpha=60^{\circ}$ における伸長率の違いによる光透過率の異方性を示す. 空 隙部が正方形に近いとき, すなわち $w$ と $c$ がほぼ同じ值 となるときは $45^{\circ} ， 135^{\circ} ， 225^{\circ} ， 315^{\circ}$ 方向に高い值を 示す $\pi / 2$ 周期の異方性が, 空隙が細長くなると長くなった 方向へ高い值を示す $\pi$ 周期の異方性が現れた. 光透過異方 性は空隙部の形状に大きく影響される．試料 A について も同様であった。

\section{2 二軸伸長時の光透過性}

\section{2.1 伸長による密度の変化}

図 13 に伸長に伴うウェール密度およびコース密度の変 化を示す. 2.2.2で述べた通りウェール方向に伸張すると, ウェール密度は変化しないが, コース密度がひずみに反比 例して減少し, コース方向に伸張すると逆に, コース密度 は変化しないが, ウェール密度が伸張率に反比例して減少 した. 両方向に伸長した場合も式 7 のような結果となった. よって, 同面積に伸長させた場合はウェール密度 $W$ 'とコ ース密度 $C$ ’を乗した值は同じになった。

\section{2.2 光透過率の測定值と理論值の比較}

図 14 に光を試料正面から照射したときの透過率と， $W$ ' $\times C^{\prime}$ との関係を示す。 $W^{\prime} \times C^{\prime}$ の值が小さくなる（伸長率 が大きくなる）につれ，透過率は大きくなった．これは， 伸長により空隙面積が大きくなったためであり, 当然の結 果である. 同一試料の場合, 伸長方向に関わらず, $W^{\prime} \times C^{\prime}$ の值が同じとき, すなわち同面積に伸長させたときの透過 率はほぼ同じ值となった。しかし, 試料 A と B とを比較 すると，同じ透過率でも $W^{\prime} \times C^{\prime}$ の值が異なっている，こ れは $W^{\prime} \times C^{\prime}$ の值が同じであっても, 原糸にかかる荷重が 異なるため糸の直径に違いがあるからである.

表 5 に式 9 より求めた, 試料の原糸 1 本あたりに掛かる 荷重を示す.この值と図 9 の関係から伸長時の原糸の直径 を求め, 式 8 より光透過率の理論值を求めた。 図 15 に試 料 A における測定值と理論值との比較を示す. どの方向 に伸長させた場合でも, 測定值と理論值はほぼ等しくなっ た. 試料 B についても同様の結果となった. よって, 無 伸長時のウェール密度, コース密度と伸長時の原糸の直径 が分かれば, 伸長状態での光を正面から照射したときの光 透過率を予測することができる.

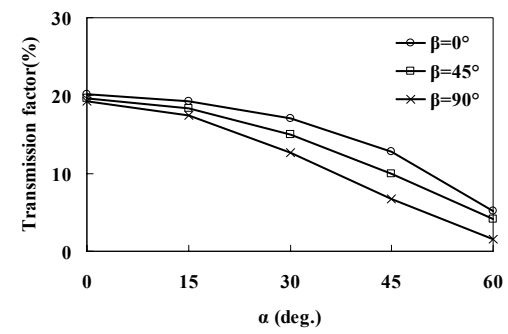

Fig. 11 Light transmission factor for a change of $\alpha$ $\left(\mathrm{B}_{\mathrm{u}} \mathrm{C} 75\right)$.

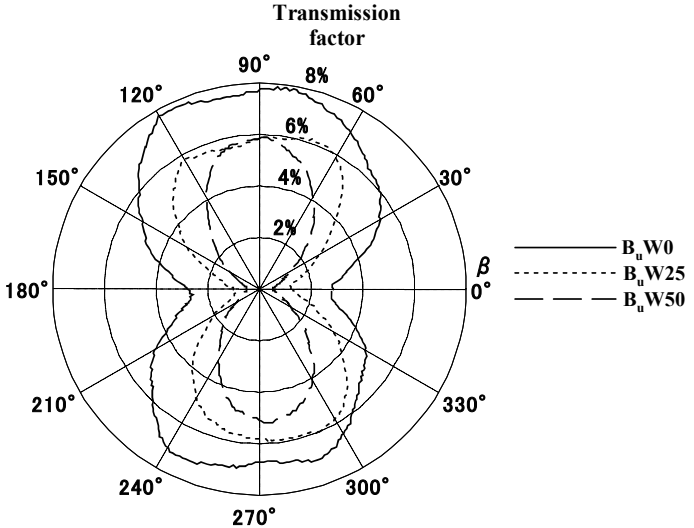

(a) Extension along wale direction.

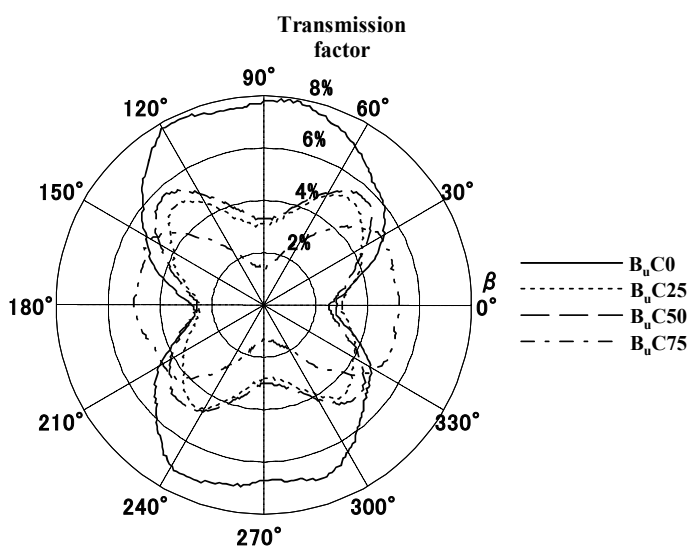

(b) Extension along course direction.

Fig.12 Anisotropy of light transmission factor at $\alpha$ $=60^{\circ}$ (sample B).

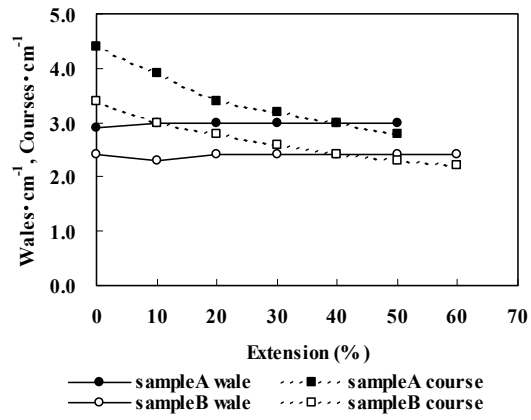

(a) Extension along wale direction.

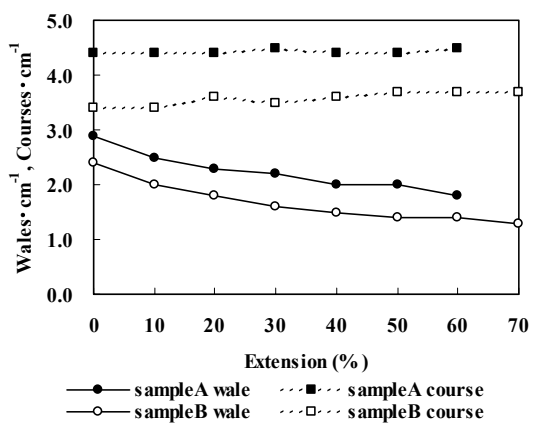

(b) Extension along course direction.

Fig. 13 Relationship between extension and stitch density of wale or course (biaxial extension). 


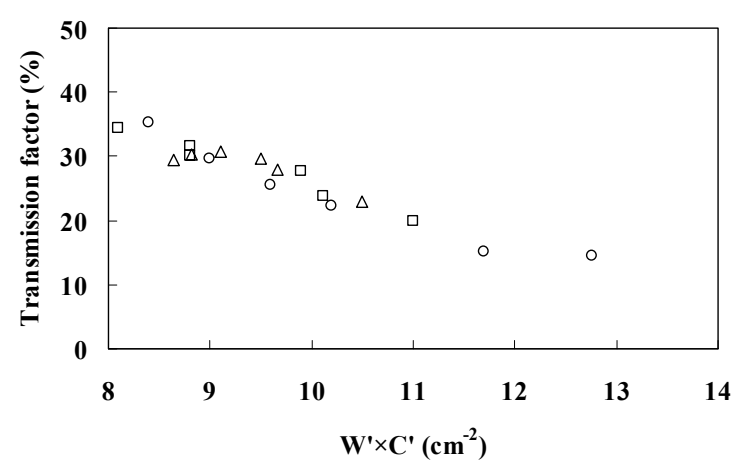

o wale direction $\square$ course direction $\Delta$ wale-course direction

(a) Sample A

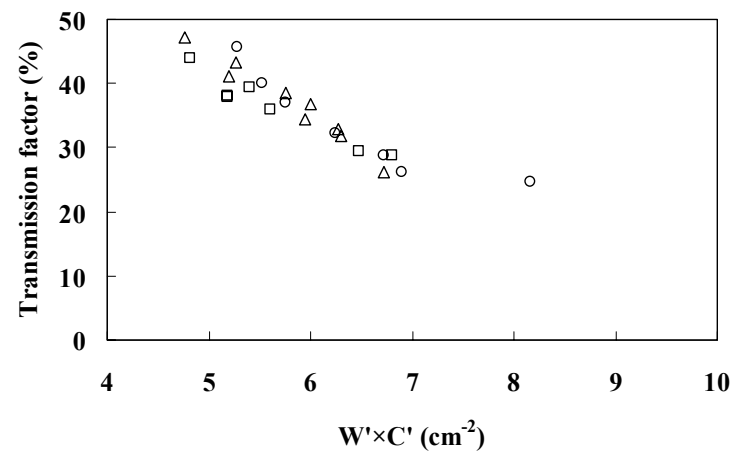

$\circ$ wale direction $\square$ course direction $\Delta$ wale-course direction

(b) Sample B

Fig. 14 Relationship between $W^{\prime} \times C^{\prime}$ and transmission factor.

Table 5 Calculated load of yarn in fabric (biaxial extension).

Sample A

\begin{tabular}{|c|c|c|c|c|c|}
\hline $\begin{array}{l}\text { sample } \\
\text { name }\end{array}$ & $\begin{array}{l}\text { load } \\
\text { (gf) }\end{array}$ & $\begin{array}{l}\text { sample } \\
\text { name }\end{array}$ & $\begin{array}{l}\text { load } \\
\text { (gf) }\end{array}$ & $\begin{array}{c}\text { sample } \\
\text { name }\end{array}$ & $\begin{array}{l}\text { load } \\
\text { (gf) }\end{array}$ \\
\hline $\mathrm{A}_{b} 0-0$ & 0.00 & $A_{b} 0-10$ & 1.16 & $A_{b} 10-10$ & 8.82 \\
\hline$A_{b} 10-0$ & 2.33 & $A_{b} 0-20$ & 3.49 & $\mathrm{~A}_{\mathrm{b}} 10-20$ & 20.59 \\
\hline $\mathrm{A}_{\mathrm{b}} 20-0$ & 4.65 & $A_{b} 0-30$ & 6.98 & $A_{b} 10-30$ & 48.53 \\
\hline $\mathrm{A}_{\mathrm{b}} 30-0$ & 16.28 & $\mathrm{~A}_{b} 0-40$ & 16.28 & $\mathrm{~A}_{\mathrm{b}} 20-10$ & 20.59 \\
\hline$A_{b} 40-0$ & 86.05 & $A_{b} 0-50$ & 39.53 & $A_{b} 20-20$ & 89.71 \\
\hline$A_{b} 50-0$ & 188.37 & $A_{b} 0-60$ & 110.47 & $\mathrm{~A}_{\mathrm{b}} 30-10$ & 39.71 \\
\hline \multicolumn{6}{|c|}{ Sample B } \\
\hline $\begin{array}{l}\text { sample } \\
\text { name }\end{array}$ & $\begin{array}{l}\text { load } \\
\text { (gf) }\end{array}$ & $\begin{array}{l}\text { sample } \\
\text { name }\end{array}$ & $\begin{array}{l}\text { load } \\
(\mathrm{gf})\end{array}$ & $\begin{array}{l}\text { sample } \\
\text { name }\end{array}$ & $\begin{array}{l}\text { load } \\
\text { (gf) }\end{array}$ \\
\hline $\mathrm{B}_{b} 0-0$ & 0.00 & $\mathrm{~B}_{\mathrm{b}} 10-0$ & 1.47 & $\mathrm{~B}_{\mathrm{b}} 10-10$ & 1.32 \\
\hline $\mathrm{B}_{\mathrm{b}} 0-10$ & 0.29 & $\mathrm{~B}_{\mathrm{b}} 20-0$ & 2.94 & $\mathrm{~B}_{\mathrm{b}} 10-20$ & 2.79 \\
\hline $\mathrm{B}_{\mathrm{b}} 0-20$ & 1.47 & $\mathrm{~B}_{\mathrm{b}} 30-0$ & 4.41 & $\mathrm{~B}_{\mathrm{b}} 10-30$ & 6.18 \\
\hline $\mathrm{B}_{\mathrm{b}} 0-30$ & 4.41 & $\mathrm{~B}_{\mathrm{b}} 40-0$ & 10.29 & $\mathrm{~B}_{\mathrm{b}} 20-10$ & 3.53 \\
\hline $\mathrm{B}_{\mathrm{b}} 0-40$ & 14.71 & $\mathrm{~B}_{\mathrm{b}} 50-0$ & 26.47 & $\mathrm{~B}_{\mathrm{b}} 20-20$ & 7.65 \\
\hline $\mathrm{B}_{\mathrm{b}} 0-50$ & 61.76 & $\mathrm{~B}_{\mathrm{b}} 60-0$ & 86.76 & $\mathrm{~B}_{\mathrm{b}} 20-30$ & 17.06 \\
\hline $\mathrm{B}_{\mathrm{b}} 0-60$ & 194.12 & $\mathrm{~B}_{\mathrm{b}} 70-0$ & 227.94 & $\mathrm{~B}_{\mathrm{b}} 30-10$ & 22.94 \\
\hline- & - & - & - & $\mathrm{B}_{\mathrm{b}} 30-20$ & 60.00 \\
\hline- & - & - & - & $\mathrm{B}_{\mathrm{b}} 30-30$ & 116.18 \\
\hline
\end{tabular}

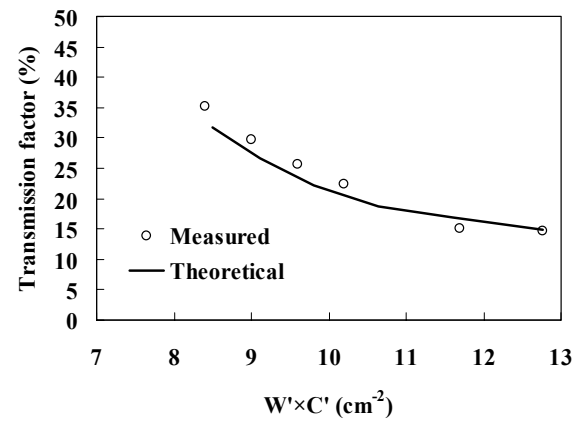

(a) Extension along wale direction.

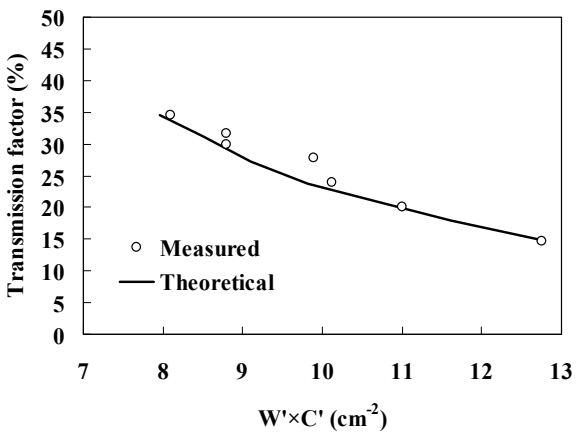

(b) Extension along course direction.

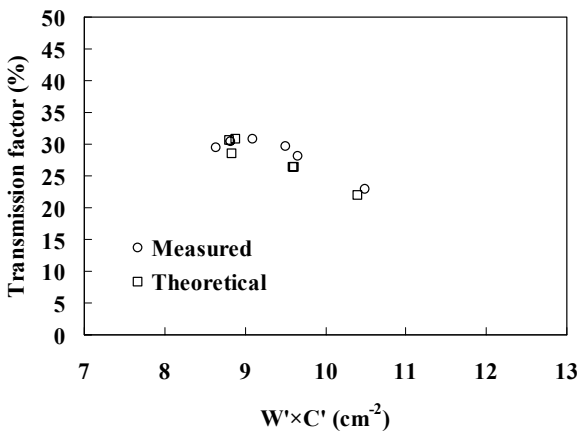

(c) Extension along wale and course direction.

Fig. 15 Comparison between measured and theoretical values of light transmission factor (Sample A, biaxial extension).

\section{2.3 光透過異方性}

一軸を拘束して伸長させた試料では， $\alpha$ が大きくなるに つれ光透過率に異方性が現れた. また, この異方性は伸長 率が大きいほど, $\alpha$ が小さい段階から現れた. しかし, 図 16 に示すように二軸伸長では, ウェール方向とコース方 向に同等に伸長させた場合では, それほど顕著な異方性は 現れなかった. 図 17 に, 試料 A の $\alpha=60^{\circ}$ における伸長 率の違いによる光透過率の異方性を示す. 伸長率が小さい ときは, $45^{\circ}, 135^{\circ}, 225^{\circ}, 315^{\circ}$ 方向に高い值を示す $\pi / 2$ 周期の異方性が, 伸長率が大きくなるにつれ, 伸長方 向に高い值を示す $\pi$ 周期の異方性が確認された. 空隙部が 正方形よりも細長くなるほど異方性が顕著であることが 分かった. このように, 同面積に伸長させた場合でも, $\alpha$ が大きいときは伸長条件の違いにより様々な光透過異方 性を示した．試料 Bについても同様であった。 


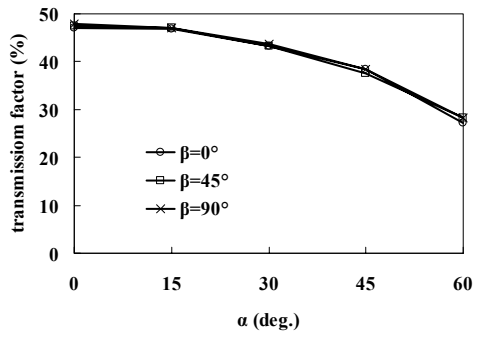

Fig. 16 Light transmission factor for a change of $\alpha$ $\left(\mathrm{B}_{\mathrm{b}} 30-30\right)$.

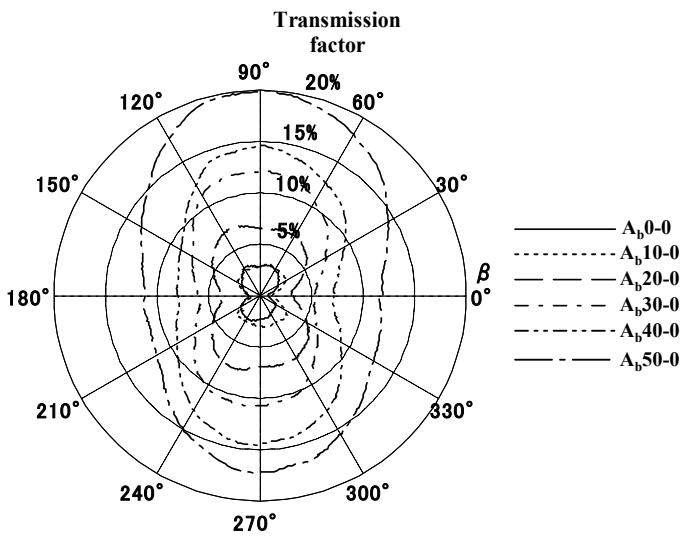

(a) Extension along wale direction.

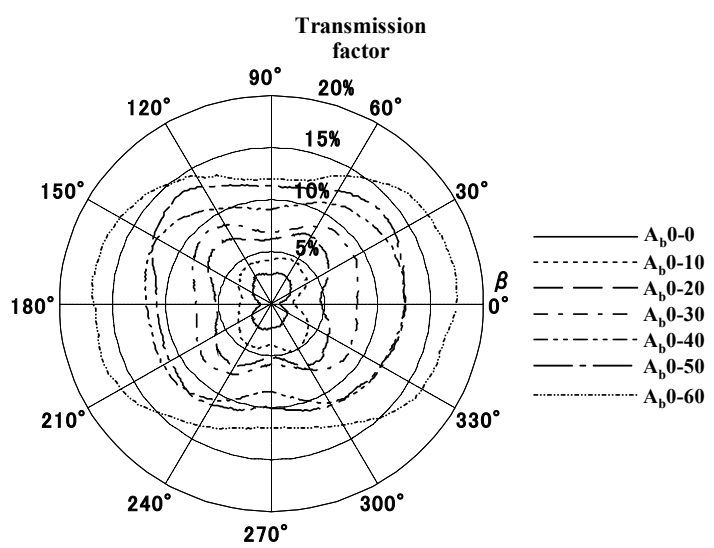

(b) Extension along course direction.

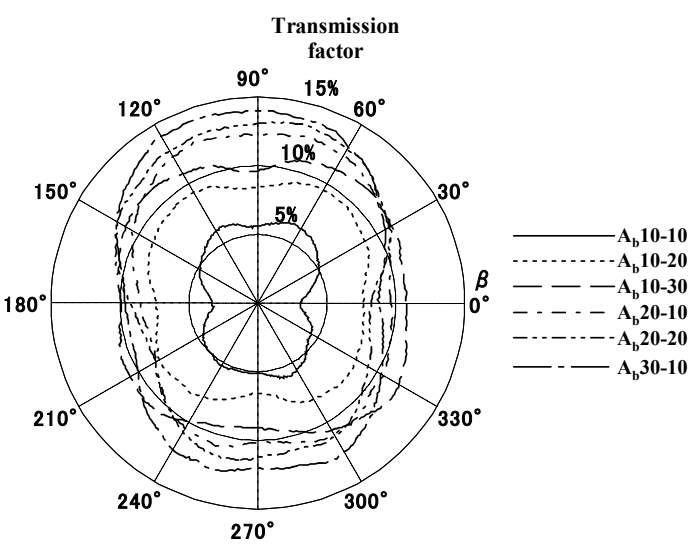

(c) Extension along wale and course direction.

Fig.17 Anisotropy of light transmission factor at $\alpha$ $=60^{\circ}$ (sample A).

\section{5. 結 言}

一軸伸長および二軸伸長状態における平編物の光透過 性の異方性測定を行ない, 伸長率と光透過異方性との関係 を検討した。

糸の透過率が 0 であれば, 一軸伸長の場合は, ポアソン 比の大小により, 引張に伴うウェール密度とコース密度と の変化が異なるため, 同じ伸長率でも伸長方向の違いで透 過率は異なった. 無伸長時のウェール密度, コース密度, 伸長時の原糸の直径変化, 編地のポアソン比が分かれば, 伸長状態での光を正面から照射したときの光透過率を予 測することができる，また，伸長条件の違いにより，さま ざまな異方性が確認された. 二軸伸長の場合は, 同一試料 であれば伸長方向に関わらず同面積に伸長した場合, 透過 率は同じ值となった. よって, 無伸長時のウェール密度, コース密度と伸長時の原糸の直径変化が分かれば, 伸長状 態での光を正面から照射したときの光透過率を予測する ことができる. しかし, 同面積に伸長させた場合でも伸長 条件の違いにより光透過異方性に違いがあることが確認 された.

光透過異方性には空隙部の形状と関係があり, また伸長 により編物の厚さが変化し, このことも関係していると考 えられ, 光透過異方性の予測には編物の三次元構造とその 変形モデルが必要である.

本研究は 21 世紀 COE および科学研究費助成金(基盤研究 C(2)16500124)の補助を受けた。

\section{文 献}

1. M. Sugano, N. Katsuragi, T. Sakai, T. Sakai, Kasei Gakkaishi, 52, 943 (2001).

2. S. Yoshino, J. Akashi, T. Yamanaka, E. Horita, Sen'i Seihin Shohi Kagaku, 41, 682 (2000).

3. Y. Matsumoto, H. Morooka, Sen'i Seihin Shohi Kagaku, 38, 711 (1997).

4. H. Morooka, K. Wakashima, Y. Azuma, Y.Matsumoto, H. Morooka, Sen'i Kikai Gakkaishi, 52, 186 (1999).

5. H. Morooka, K. Wakashima, Y.Matsumoto, H. Morooka, Textile Res. J., 69, 68 (1999).

6. N. Naruse, H. Igarashi, K. Nihira, Sen'i Gakkaishi, 33, 444 (1977).

7. N. Kusakabe, K. Furusato, Sen'i Seihin Shohi Kagaku, 24, 191 (1983).

8. Y. Yazaki, M. Takatera, Y. Shimizu, Sen'i Gakkaishi, 60, 281 (2004).

9. G. E. Chadwick, S. A. Shorter, K. Weissenberg, J. Text. Inst., 40, 111 (1949). 